\title{
Socio-ethogram of adult males versus biochemical-genetic variation in assessing phylogenetic relationships of the Caprinae
}

\author{
Fred KURT and Günther B. HARTL
}

\begin{abstract}
Kurt F. and Hartl G. B. 1995. Socio-ethogram of adult males versus biochemical-genetic variation in assessing phylogenetic relationships of the Caprinae. [In: Ecological genetics in mammals II. G. B. Hartl and J. Markowski, eds]. Acta Theriologica,
\end{abstract} Suppl. 3: 183-197.

To investigate phylogenetic relationships among 9 genera of the Caprinae (Capra, Ammotragus, Hemitragus, Pseudois, Ovis, Rupicapra, Oreamnos, Nemorhaedus, Capricornis) behaviours involved in courtship and mating, aggression, threat, dominance, submission, and marking of adult males were subjected to phylogenetic analysis. Based on all 32 characters and 96 character states investigated, phylogenetic patterns generally were in good agreement with biochemical-genetic data avaliable. Discordance between phylogenetic trees constructed from behavioural and from biochemical-genetic traits as to the position of Ammotragus turned out to be associated with ethological functional categories. Behaviours involved in courtship and mating were identified as the most reliable ones for phylogenetic studies. Courtship displays function as isolation mechanisms among closely related taxa. This is of paramount importance in those forms where secondary sexual characters such as horns are poorly differentiated while in highly evolved taxa size and shape of horns may also trigger readiness for mating in estrous females.

Institut für Haustierkunde der Christian-Albrechts-Universität zu Kiel, Olshausenstraße 40, D-24118 Kiel, Germany

Key words: Caprinae, socio-ethogram, ritualized behaviour, allozymes, phylogeny

\section{Introduction}

Heinroth (1910) was one of the first to postulate that behavioural patterns can be used as taxonomic characters. In ungulates, social behaviours were compared from a systematic point of view by Walther (eg 1974) and Estes (eg 1991). In Caprinae, more or less comprehensive comparisons between species and subspecies have been carried out by Schaller and Laurie (1974), Schaller (1977), Habibi (1987), Cavallini (1987), Rice (1988, 1995), and Lovari and Apollonio (1994). However, the respective analyses covered only a small part of the whole taxon, relied on uncomplete socio-ethograms, did not consider the function of the respective behavioural patterns, and were not subjected to direct phylogenetic analyses using one or more of the various mathematical approaches available. As long as complex behaviours are concerned, a quantitative phylogenetic evaluation is indeed difficult 
and not very promising. However, complex behaviours consist of surprisingly stereotypic sequences of simple patterns, which can be described and homologized among closely related taxa. Many of those patterns became ritualized and may have changed their functional context. They rather tended to diversify among taxa than to get lost. Some of them may have disappeared from the behavioural repertoire of adult males for some time, but survived in what is considered play behaviour of juveniles, and may have suddenly reappeared in one or the other form. In general, it is recommendable to restrict a comparative phylogenetic analysis to the socio-ethogram of adult males. These patterns are richest in details and variation, most obvious, best described, and are involved in sexual selection. By playing a role in mate choice and competition for mates these characters are most likely relevant for reproductive isolation and the separation of species.

Phylogenetic relationships among genera of the Caprinae are still an unsettled issue (see Hartl 1995 for a review). According to the classical taxonomic opinion the genera Capra (goat), Ovis (sheep), Ammotragus (aoudad), Hemitragus (tahr), and Pseudois (bharal) are assigned to the tribus Caprini. The genera Rupicapra (chamois), Oreamnos (Rocky Mountain goat), Capricornis (serow), and Nemorhaedus (goral) are assigned to a different tribus, the Rupicaprini (Thenius 1969, Schaller, 1977). Part of the genera (Capra, Ovis, Rupicapra, Oreamnos, Hemitragus, and Ammotragus) have been subjected to phylogenetic analyses using allozyme electrophoresis. While the tahr and the aoudad were quite closely related to the goats, the classification of sheep and goat on the one hand, and of the chamois and the Rocky mountain goat on the other into two different tribus turned out to be not supported by biochemical-genetic data. In fact genetic divergence among Ovis, Capra, and Rupicapra was very similar. These results can be interpreted in two different ways (cf Hartl et al. 1990a): 1. The three groups separated from an assumed common rupicaprine ancestor (Geist 1971) at about the same time, and then differentiated from one another at a rather constant evolutionary rate (Randi et al. 1991). 2. Ovis and Capra had a common ancestor, which first separated from the rupicaprine line and later split into two forms leading to the extant sheep and goats, respectively. In this case, biochemical evolutionary rates in Ovis and Capra must have been accelerated relative to that of Rupicapra, possibly as a result of rapid adaptive radiations during the Pleistocene (Hartl et al. 1990a, b, Hartl 1995).

In the present paper phenetic and cladistic analysis of behavioural elements are used for testing the aforementioned hypotheses. Furthermore, the systematic position of Ammotragus, previously considered a linking form between sheep and goat (Thenius 1969, Geist 1971), and of the genera Capricornis, Nemorhaedus, and Pseudois, not included in biochemical-genetic studies so far, is investigated.

\section{Material and methods}

Socio-ethograms for nine genera of the Caprinae (Capricornis, Nemorhaedus, Oreamnos, Rupicapra, Ammotragus, Pseudois, Hemitragus, Capra, and Ovis) were compiled. The nilgai antelope 
(Boselaphus tragocamelus), also included in previous biochemical-genetic analyses, served as an outgroup. For our analysis we considered only the presence or absence of behaviours found in the other taxa studied as well as some typical nilgai behaviours. But a complete socio-ethogram of nilgai male is not yet available. Thus, the outgroup is used for cladistic analyses (where autapomorphies are unimportant) but excluded from phenetic analyses (where an incomplete set of autapomorphies would lead to an underestimation of overall distance values). Behavioural elements are defined and assigned to different functional categories in the Appendix). In the terminology we generally followed current usage. In cases where different authors used different terms for the same patterns, the respective synonyms are given in parentheses. Social behaviours of adult males fall into the following functional categories: agonistic, sexual, and space-claim behaviour. Agonistic behaviour can be subdivided in agonistic acts (ie fighting, AA), dominance displays (DD), threat displays (TD), and submissive displays (SD). Sexual behaviour consists of sexual acts (ie mating) and courtship displays (CD). Space-claim behaviour consists of patterns in which a male olfactorily marks its home range (MA). In some cases one and the same pattern is found in more than a single functional context. In this case it was mentioned in all categories it appears. Behavaioural patterns are therefore also defined by the functional context they appear in.

For phylogenetic analyses single behaviours were treated as characters and their variants (including absence) as character states. Binary codes for behaviours involved in the aforementioned functional categories are presented in Tables 1-4. For phenetic analysis, pairwise dissimilarity among taxa was estimated using the measure of "total difference" (number of characters differing between two taxa / total number of characters investigated; Quicke 1993). Phenetic trees were constructed using the FITCH option in the PHYLIP programme of Felsenstein (Felsenstein 1993). Cladistic analysis was performed using the MIX option (WAGNER-parsimony) in PHYLIP. Furthermore, HENNIGian cladograms were constructed by hand following the criteria outlined in Hartl et al. (1990a).

Table 1. Aggressive actions between adult males. Behavioural elements are characters (Char.), and their respective ritualizations [including the absence $=(-)$ ] are character states (Char. st.). Occurrence (absence) of a character state in all species of a genus studied so far is marked by $1(0)$. In the case an element occurs only in part of the species of a genus examined it is marked by an asterisk. A Capricornis, B - Nemorhaedus, C - Oreamnos, D - Rupicapra, E - Ammotragus, F - Pseudois, G Hemitragus, H - Capra, I - Ovis, J - Boselaphus tragocamelus. For more explanations and sources of data see Appendix.

\begin{tabular}{llllllllllll}
\hline Char. & Char. st. & A & B & C & D & E & F & G & H & I & J \\
\hline Ch & Ch & 1 & 1 & 1 & 1 & 1 & 1 & 1 & 1 & 1 & 1 \\
$\mathrm{Ki}$ & $\mathrm{Ki}$ & 1 & 0 & 0 & 0 & 0 & 1 & 0 & 0 & 1 & 0 \\
& $\mathrm{Ki}(-)$ & 0 & 1 & 1 & 1 & 1 & 0 & 1 & 1 & 0 & 1 \\
$\mathrm{Rf}$ & $\mathrm{Rf}$ & 0 & 0 & 1 & 0 & 1 & 0 & 1 & 0 & 0 & 0 \\
& $\mathrm{Sp}$ & 1 & 0 & 0 & 0 & 1 & 0 & 0 & 0 & 1 & 0 \\
& $\mathrm{Nf}$ & 0 & 0 & 0 & 0 & 1 & 0 & 1 & 0 & 0 & 0 \\
& $\mathrm{Nk}$ & 0 & 0 & 0 & 0 & 0 & 0 & 0 & 0 & 0 & 1 \\
& $\mathrm{Rf}(-)$ & 0 & 1 & 0 & 1 & 0 & 1 & 0 & 1 & 0 & 0 \\
$\mathrm{Hp}$ & $\mathrm{Hp}$ & 0 & 0 & 0 & 0 & 1 & 0 & 0 & 0 & $1^{*}$ & 0 \\
& $\mathrm{Hp}(-)$ & 1 & 1 & 1 & 1 & 0 & 1 & 1 & 1 & $1^{*}$ & 1 \\
$\mathrm{Bt}$ & $\mathrm{Bt}$ & 1 & 1 & 1 & 1 & 1 & 1 & 1 & 1 & 1 & 0 \\
& $\mathrm{Co}$ & 1 & 1 & 0 & 0 & 1 & 1 & 1 & 1 & 1 & 0 \\
& $\mathrm{Cu}$ & 0 & 0 & 0 & 0 & 0 & 1 & 1 & 1 & 0 & 0 \\
& $\mathrm{Cr}$ & 0 & 0 & 0 & 0 & 1 & 1 & 0 & 0 & $1^{*}$ & 0 \\
& $\mathrm{Cp}$ & 0 & 0 & 0 & 0 & 0 & 0 & 0 & 0 & $1^{*}$ & 0 \\
& $\mathrm{Ck}$ & 0 & 0 & 0 & 0 & 0 & 0 & 0 & 0 & 0 & 1 \\
\hline
\end{tabular}


Table 2. Threat displays [from $\mathrm{Hr}$ to $\mathrm{Hd}(-)$ ], dominance displays [from St to $\mathrm{Su}(-)$ ], and submissive displays [from Uf to $\mathrm{Rb}(-)$ ] between adult males. For explanations of symbols see Table 1 .

\begin{tabular}{|c|c|c|c|c|c|c|c|c|c|c|c|}
\hline Char. & Char. st. & $\mathrm{A}$ & B & C & $\mathrm{D}$ & $\mathrm{E}$ & $\mathrm{F}$ & $\mathrm{G}$ & $\mathrm{H}$ & $\mathrm{I}$ & $\mathrm{J}$ \\
\hline $\mathrm{Hr}$ & $\begin{array}{l}\mathrm{Hr} \\
\mathrm{Hk} \\
\mathrm{Lu} \\
\mathrm{Dd}\end{array}$ & $\begin{array}{l}1 \\
1 \\
0 \\
0\end{array}$ & $\begin{array}{l}0 \\
1 \\
1 \\
0\end{array}$ & $\begin{array}{l}1 \\
1 \\
1 \\
0\end{array}$ & $\begin{array}{l}1 \\
1 \\
1^{*} \\
0\end{array}$ & $\begin{array}{l}0 \\
1 \\
1 \\
0\end{array}$ & $\begin{array}{l}1 \\
1 \\
1 \\
0\end{array}$ & $\begin{array}{l}1 \\
1 \\
1 \\
0\end{array}$ & $\begin{array}{l}1 \\
1 \\
1 \\
0\end{array}$ & $\begin{array}{l}1 \\
1 \\
1 \\
0\end{array}$ & $\begin{array}{l}0 \\
0 \\
0 \\
1\end{array}$ \\
\hline $\mathrm{Ga}$ & $\begin{array}{l}\mathrm{Ga} \\
\mathrm{Jf} \\
\mathrm{Ju} \\
\mathrm{Ga}(-)\end{array}$ & $\begin{array}{l}0 \\
0 \\
0 \\
1\end{array}$ & $\begin{array}{l}1 \\
0 \\
0 \\
0\end{array}$ & $\begin{array}{l}1 \\
0 \\
0 \\
0\end{array}$ & $\begin{array}{l}1 \\
0 \\
0 \\
0\end{array}$ & $\begin{array}{l}0 \\
0 \\
0 \\
1\end{array}$ & $\begin{array}{l}0 \\
0 \\
1 \\
0\end{array}$ & $\begin{array}{l}0 \\
0 \\
1 \\
0\end{array}$ & $\begin{array}{l}0 \\
0 \\
1 \\
0\end{array}$ & $\begin{array}{l}0 \\
1 \\
0 \\
0\end{array}$ & $\begin{array}{l}0 \\
0 \\
0 \\
1\end{array}$ \\
\hline $\mathrm{Hd}$ & $\begin{array}{l}\mathrm{Hd} \\
\mathrm{Hs} \\
\mathrm{Hd}(-)\end{array}$ & $\begin{array}{l}1 \\
0 \\
0\end{array}$ & $\begin{array}{l}0 \\
0 \\
1\end{array}$ & $\begin{array}{l}1 \\
1 \\
0\end{array}$ & $\begin{array}{l}1 \\
0 \\
0\end{array}$ & $\begin{array}{l}0 \\
0 \\
1\end{array}$ & $\begin{array}{l}1 \\
0 \\
0\end{array}$ & $\begin{array}{l}1 \\
1 \\
0\end{array}$ & $\begin{array}{l}1^{*} \\
0 \\
1^{*}\end{array}$ & $\begin{array}{l}1^{*} \\
0 \\
1^{*}\end{array}$ & $\begin{array}{l}0 \\
0 \\
1\end{array}$ \\
\hline St & $\begin{array}{l}\text { St } \\
\text { St(-) }\end{array}$ & $\begin{array}{l}0 \\
1\end{array}$ & $\begin{array}{l}1 \\
0\end{array}$ & $\begin{array}{l}1 \\
0\end{array}$ & $\begin{array}{l}1 \\
0\end{array}$ & $\begin{array}{l}0 \\
1\end{array}$ & $\begin{array}{l}0 \\
1\end{array}$ & $\begin{array}{l}1 \\
0\end{array}$ & $\begin{array}{l}0 \\
1\end{array}$ & $\begin{array}{l}1 \\
0\end{array}$ & $\begin{array}{l}0 \\
1\end{array}$ \\
\hline $\mathrm{Hu}$ & $\begin{array}{l}\mathrm{Hu} \\
\mathrm{Hf} \\
\mathrm{Ht} \\
\mathrm{Bl} \\
\mathrm{Hu}(-)\end{array}$ & $\begin{array}{l}0 \\
0 \\
0 \\
0 \\
1\end{array}$ & $\begin{array}{l}0 \\
0 \\
0 \\
0 \\
1\end{array}$ & $\begin{array}{l}0 \\
0 \\
1 \\
0 \\
0\end{array}$ & $\begin{array}{l}0 \\
0 \\
0 \\
0 \\
1\end{array}$ & $\begin{array}{l}0 \\
0 \\
0 \\
0 \\
1\end{array}$ & $\begin{array}{l}1 \\
0 \\
0 \\
1 \\
0\end{array}$ & $\begin{array}{l}0 \\
0 \\
1 \\
0 \\
0\end{array}$ & $\begin{array}{l}1^{*} \\
0 \\
1^{*} \\
1^{*} \\
0\end{array}$ & $\begin{array}{l}1 \\
0 \\
0 \\
1^{*} \\
0\end{array}$ & $\begin{array}{l}0 \\
1 \\
0 \\
0 \\
0\end{array}$ \\
\hline Pw & $\begin{array}{l}\mathrm{Pw} \\
\mathrm{Pw}(-)\end{array}$ & $\begin{array}{l}0 \\
1\end{array}$ & $\begin{array}{l}0 \\
1\end{array}$ & $\begin{array}{l}0 \\
1\end{array}$ & $\begin{array}{l}1^{*} \\
1^{*}\end{array}$ & $\begin{array}{l}0 \\
1\end{array}$ & $\begin{array}{l}1 \\
0\end{array}$ & $\begin{array}{l}0 \\
1\end{array}$ & $\begin{array}{l}1^{*} \\
1^{*}\end{array}$ & $\begin{array}{l}1^{*} \\
1^{*}\end{array}$ & $\begin{array}{l}0 \\
1\end{array}$ \\
\hline Ls & $\begin{array}{l}\mathrm{Ls} \\
\mathrm{Ls}(-)\end{array}$ & $\begin{array}{l}0 \\
1\end{array}$ & $\begin{array}{l}0 \\
1\end{array}$ & $\begin{array}{l}0 \\
1\end{array}$ & $\begin{array}{l}0 \\
1\end{array}$ & $\begin{array}{l}1 \\
0\end{array}$ & $\begin{array}{l}1 \\
0\end{array}$ & $\begin{array}{l}0 \\
1\end{array}$ & $\begin{array}{l}0 \\
1\end{array}$ & $\begin{array}{l}1 \\
0\end{array}$ & $\begin{array}{l}0 \\
1\end{array}$ \\
\hline Mt & $\begin{array}{l}\mathrm{Mt} \\
\mathrm{Mt}(-)\end{array}$ & $\begin{array}{l}0 \\
1\end{array}$ & $\begin{array}{l}0 \\
1\end{array}$ & $\begin{array}{l}0 \\
1\end{array}$ & $\begin{array}{l}0 \\
1\end{array}$ & $\begin{array}{l}1 \\
0\end{array}$ & $\begin{array}{l}1 \\
0\end{array}$ & $\begin{array}{l}0 \\
1\end{array}$ & $\begin{array}{l}0 \\
1\end{array}$ & $\begin{array}{l}1 \\
0\end{array}$ & $\begin{array}{l}0 \\
1\end{array}$ \\
\hline $\mathrm{Ts}$ & $\begin{array}{l}\mathrm{Ts} \\
\mathrm{Tr} \\
\mathrm{Tf} \\
\mathrm{Ts}(-)\end{array}$ & $\begin{array}{l}0 \\
0 \\
0 \\
1\end{array}$ & $\begin{array}{l}0 \\
0 \\
0 \\
1\end{array}$ & $\begin{array}{l}0 \\
0 \\
0 \\
1\end{array}$ & $\begin{array}{l}0 \\
0 \\
0 \\
1\end{array}$ & $\begin{array}{l}0 \\
0 \\
0 \\
1\end{array}$ & $\begin{array}{l}0 \\
0 \\
1 \\
0\end{array}$ & $\begin{array}{l}0 \\
0 \\
0 \\
1\end{array}$ & $\begin{array}{l}0 \\
0 \\
1^{*} \\
1^{*}\end{array}$ & $\begin{array}{l}1 \\
1 \\
1 \\
0\end{array}$ & $\begin{array}{l}0 \\
0 \\
0 \\
1\end{array}$ \\
\hline $\mathrm{Fl}$ & $\begin{array}{l}\mathrm{Fl} \\
\mathrm{Fl}(-)\end{array}$ & $\begin{array}{l}0 \\
1\end{array}$ & $\begin{array}{l}0 \\
1\end{array}$ & $\begin{array}{l}0 \\
1\end{array}$ & $\begin{array}{l}1^{*} \\
1^{*}\end{array}$ & $\begin{array}{l}0 \\
1\end{array}$ & $\begin{array}{l}0 \\
1\end{array}$ & $\begin{array}{l}0 \\
1\end{array}$ & $\begin{array}{l}0 \\
1\end{array}$ & $\begin{array}{l}0 \\
1\end{array}$ & $\begin{array}{l}0 \\
1\end{array}$ \\
\hline $\mathrm{He}$ & $\begin{array}{l}\mathrm{He} \\
\mathrm{He}(-)\end{array}$ & $\begin{array}{l}0 \\
1\end{array}$ & $\begin{array}{l}0 \\
1\end{array}$ & $\begin{array}{l}0 \\
1\end{array}$ & $\begin{array}{l}0 \\
1\end{array}$ & $\begin{array}{l}0 \\
1\end{array}$ & $\begin{array}{l}1 \\
0\end{array}$ & $\begin{array}{l}0 \\
1\end{array}$ & $\begin{array}{l}0 \\
1\end{array}$ & $\begin{array}{l}1^{*} \\
1^{*}\end{array}$ & $\begin{array}{l}0 \\
1\end{array}$ \\
\hline $\mathrm{Su}$ & $\begin{array}{l}\mathrm{Su} \\
\mathrm{Bs} \\
\mathrm{Pd} \\
\mathrm{Mp} \\
\mathrm{Ej} \\
\mathrm{Su}(-)\end{array}$ & $\begin{array}{l}0 \\
0 \\
0 \\
0 \\
0 \\
1\end{array}$ & $\begin{array}{l}0 \\
1 \\
0 \\
0 \\
0 \\
0\end{array}$ & $\begin{array}{l}0 \\
0 \\
0 \\
1 \\
0 \\
0\end{array}$ & $\begin{array}{l}1 \\
1 \\
1 \\
0 \\
0 \\
0\end{array}$ & $\begin{array}{l}0 \\
0 \\
0 \\
1 \\
0 \\
0\end{array}$ & $\begin{array}{l}0 \\
0 \\
1 \\
1 \\
0 \\
0\end{array}$ & $\begin{array}{l}1 \\
0 \\
0 \\
1 \\
0 \\
0\end{array}$ & $\begin{array}{l}1 \\
0 \\
0 \\
1 \\
0 \\
0\end{array}$ & $\begin{array}{l}0 \\
0 \\
0 \\
0 \\
1 \\
0\end{array}$ & $\begin{array}{l}0 \\
0 \\
0 \\
0 \\
0 \\
1\end{array}$ \\
\hline Uf & $\begin{array}{l}\text { Uf } \\
\text { Uf(-) }\end{array}$ & $\begin{array}{l}0 \\
1\end{array}$ & $\begin{array}{l}1 \\
0\end{array}$ & $\begin{array}{l}0 \\
1\end{array}$ & $\begin{array}{l}1 \\
0\end{array}$ & $\begin{array}{l}0 \\
1\end{array}$ & $\begin{array}{l}0 \\
1\end{array}$ & $\begin{array}{l}0 \\
1\end{array}$ & $\begin{array}{l}0 \\
1\end{array}$ & $\begin{array}{l}0 \\
1\end{array}$ & $\begin{array}{l}0 \\
1\end{array}$ \\
\hline Ls & $\begin{array}{l}\mathrm{Ls} \\
\mathrm{Nl} \\
\mathrm{Ls}(-)\end{array}$ & $\begin{array}{l}1 \\
0 \\
0\end{array}$ & $\begin{array}{l}1 \\
0 \\
0\end{array}$ & $\begin{array}{l}1 \\
0 \\
0\end{array}$ & $\begin{array}{l}1 \\
0 \\
0\end{array}$ & $\begin{array}{l}0 \\
0 \\
1\end{array}$ & $\begin{array}{l}0 \\
1 \\
0\end{array}$ & $\begin{array}{l}0 \\
1 \\
0\end{array}$ & $\begin{array}{l}0 \\
1 \\
0\end{array}$ & $\begin{array}{l}0 \\
1^{*} \\
1^{*}\end{array}$ & $\begin{array}{l}0 \\
0 \\
0\end{array}$ \\
\hline $\mathrm{Rb}$ & $\begin{array}{l}\mathrm{Rb} \\
\mathrm{Hb} \\
\mathrm{Rb}(-)\end{array}$ & $\begin{array}{l}1 \\
0 \\
0\end{array}$ & $\begin{array}{l}0 \\
0 \\
1\end{array}$ & $\begin{array}{l}0 \\
0 \\
1\end{array}$ & $\begin{array}{l}0 \\
0 \\
1\end{array}$ & $\begin{array}{l}0 \\
0 \\
1\end{array}$ & $\begin{array}{l}0 \\
0 \\
1\end{array}$ & $\begin{array}{l}0 \\
0 \\
1\end{array}$ & $\begin{array}{l}0 \\
0 \\
1\end{array}$ & $\begin{array}{l}1 \\
1 \\
0\end{array}$ & $\begin{array}{l}0 \\
0 \\
1\end{array}$ \\
\hline
\end{tabular}


Table 3. Courtship display and mating of adult males. For explanations of symbols see Table 1.

\begin{tabular}{llllllllllll}
\hline Char. & Char. st. & A & B & C & D & E & F & G & H & I & J \\
\hline $\mathrm{Nn}$ & $\mathrm{Nn}$ & 1 & 1 & 1 & 1 & 1 & 1 & 1 & 1 & 1 & 1 \\
$\mathrm{Ng}$ & $\mathrm{Ng}$ & 1 & 1 & 1 & 1 & 1 & 1 & 1 & 1 & 1 & 1 \\
$\mathrm{Fl}$ & $\mathrm{Fl}$ & 1 & 1 & 1 & 1 & 1 & 1 & 1 & 1 & 1 & 1 \\
$\mathrm{~T}$ & $\mathrm{Tv}$ & 0 & 0 & 0 & 0 & 1 & 1 & 1 & 1 & 0 & 0 \\
& $\mathrm{Th}$ & 0 & 0 & 1 & 1 & 0 & 0 & 0 & 0 & 0 & 0 \\
& $\mathrm{~T}(-)$ & 1 & 1 & 0 & 0 & 0 & 0 & 0 & 0 & 1 & 1 \\
$\mathrm{Mf}$ & $\mathrm{Mf}$ & 1 & 1 & 0 & 0 & 0 & 0 & 0 & 0 & 0 & 0 \\
& $\mathrm{Mf}(-)$ & 0 & 0 & 1 & 1 & 1 & 1 & 1 & 1 & 1 & 1 \\
$\mathrm{Ls}$ & $\mathrm{Ls}$ & 1 & 1 & 1 & 0 & 1 & 1 & $1^{*}$ & 1 & 1 & 1 \\
& $\mathrm{Mk}$ & 0 & 0 & 0 & $1^{*}$ & 0 & 0 & 0 & 0 & 0 & 0 \\
& $\mathrm{Tr}$ & 0 & 0 & 0 & 0 & 1 & 1 & 1 & 1 & 1 & 0 \\
& $\mathrm{Ts}$ & 0 & 0 & 0 & 0 & 1 & 1 & 1 & 1 & 1 & 0 \\
& $\mathrm{Tf}$ & 0 & 0 & 0 & 0 & 1 & 0 & 1 & 1 & 0 & 0 \\
$\mathrm{Ct}$ & $\mathrm{Ct}$ & 1 & 1 & 1 & 0 & 0 & 0 & 0 & 0 & 1 & 1 \\
& $\mathrm{Hu}$ & 1 & 1 & 1 & 1 & 1 & 1 & 1 & 1 & 1 & 1 \\
$\mathrm{Ki}$ & $\mathrm{Ki}$ & 1 & 1 & 1 & 0 & 0 & 1 & 0 & 0 & $1^{*}$ & 0 \\
& $\mathrm{Ks}$ & 0 & 0 & 0 & 0 & 0 & 1 & 0 & $1^{*}$ & $1^{*}$ & 0 \\
& $\mathrm{Kf}$ & 0 & 0 & 0 & 0 & 0 & 1 & 1 & $1^{*}$ & 0 & 0 \\
& $\mathrm{~Pa}$ & 0 & 0 & 0 & $1^{*}$ & 0 & 0 & 0 & 0 & 0 & 0 \\
& $\mathrm{Fs}$ & 0 & 1 & 1 & $1^{*}$ & 0 & 0 & 0 & 0 & 0 & 0 \\
& $\mathrm{Ki}(-)$ & 0 & 0 & 0 & 0 & 1 & 0 & 0 & 0 & 0 & 1 \\
$\mathrm{Ap}$ & $\mathrm{Ap}$ & 1 & 0 & 0 & 0 & 0 & 0 & 0 & 0 & 1 & 1 \\
& $\mathrm{Ap}(-)$ & 0 & 1 & 1 & 1 & 1 & 1 & 1 & 1 & 0 & 0 \\
\hline \multirow{4}{*}{} & & & & & & & & & & &
\end{tabular}

Table 4. Marking behaviour of adult males. Explanation of symbols as in Table 1.

\begin{tabular}{llllllllllll}
\hline Char. & Char. st. & A & B & C & D & E & F & G & H & I & J \\
\hline $\mathrm{Dp}$ & $\mathrm{Dp}$ & 1 & 1 & 0 & 0 & 0 & 0 & 0 & 0 & 0 & 1 \\
& $\mathrm{Dp}(-)$ & 0 & 0 & 1 & 1 & 1 & 1 & 1 & 1 & 1 & 0 \\
$\mathrm{Ho}$ & $\mathrm{Ho}$ & 1 & 1 & 1 & 1 & 1 & 1 & 1 & 1 & 1 & 0 \\
& $\mathrm{Bf}$ & 0 & 0 & 1 & 0 & 1 & 0 & 1 & 0 & 0 & 0 \\
& $\mathrm{Mv}$ & 1 & 1 & 0 & 0 & 0 & 0 & 0 & 0 & 0 & 0 \\
& $\mathrm{Ms}$ & 0 & 1 & 1 & 1 & 0 & 0 & 0 & 0 & 0 & 0 \\
& $\mathrm{Ho}(-)$ & 0 & 0 & 0 & 0 & 0 & 0 & 0 & 0 & 0 & 1 \\
$\mathrm{~Pa}$ & $\mathrm{~Pa}$ & 1 & 0 & 1 & 1 & 0 & 0 & 1 & 0 & $1 *$ & 0 \\
& $\mathrm{Dr}$ & 0 & 0 & 1 & 0 & 0 & 0 & 0 & 0 & 0 & 0 \\
& $\mathrm{Dw}$ & 0 & 0 & 0 & 0 & 1 & 0 & 0 & 0 & 0 & 0 \\
& $\mathrm{~Pa}(-)$ & 0 & 1 & 0 & 0 & 0 & 1 & 0 & 1 & 0 & 1 \\
\hline
\end{tabular}

\section{Results}

In a first approach we used all 96 character states available (Tables 1-4) for examining phylogenetic relationships only among the taxa included in previous 
(a)

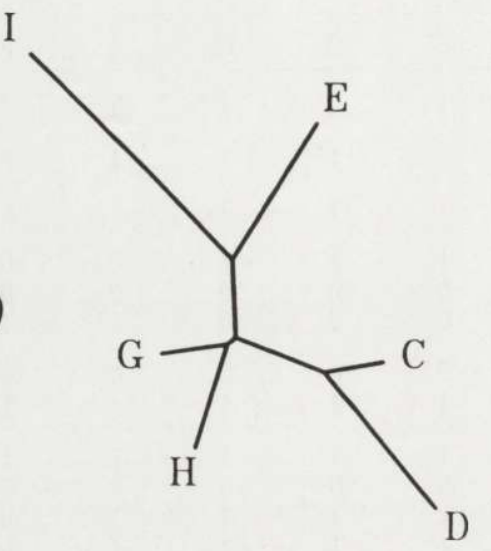

(b)

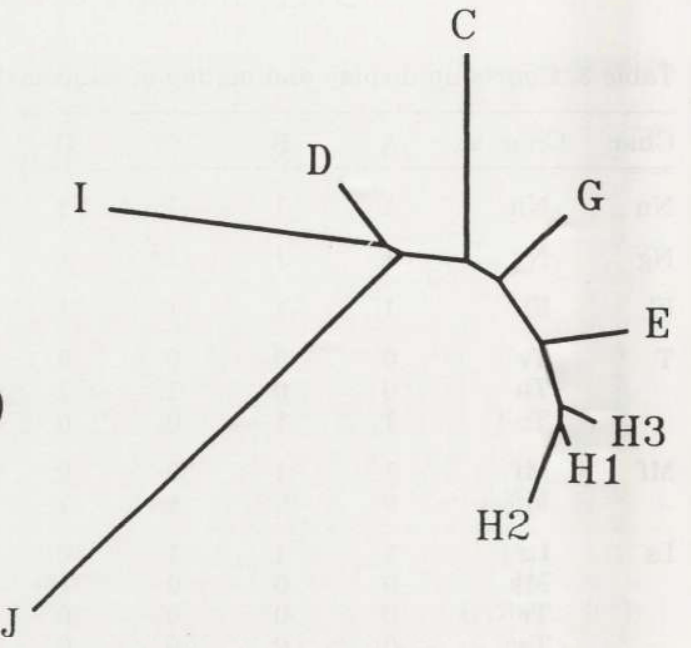

Fig. 1. Fitch-Margoliash trees based on (a) 96 behavioural character states (total distance from $\mathrm{G}$ to node is 0.060 ), and (b) allelic variation at 27 enzyme loci [Nei's (1978) $D$ from G to node is 0.106 , data from Hartl et al. 1990b] showing phylogenetic relationships among taxa of the Caprinae. J Boselaphus tragocamelus (outgroup), C - Oreamnos, D - Rupicapra, E - Ammotragus, G - Hemitragus, H - Capra (H1 - Capra aegagrus, H2 - Capra falconeri, H3 - Capra ibex), I - Ovis.

(a)

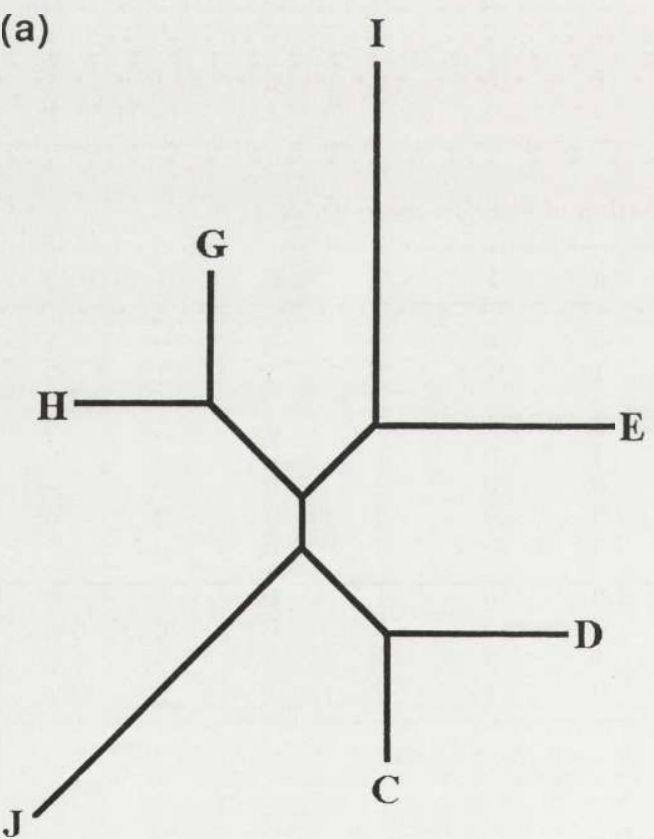

(b)

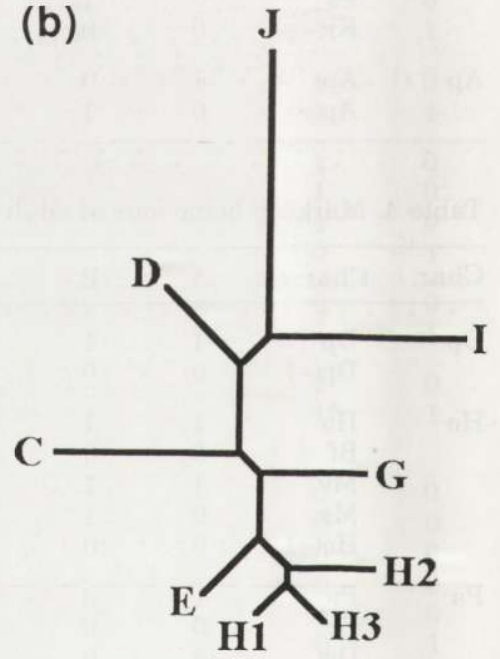

Fig. 2. Maximum-parsimony trees based on (a) 96 behavioural character states, and (b) allelic variation at 27 enzyme loci (data from Hartl et al. 1990b) showing phylogenetic relationships among taxa of the Caprinae. Branch lengths correspond to numbers of character state transformations and the distance from $H(D)$ to the node in $2 a(2 b)$ represents $10(8)$ steps. See Fig. 1 for explanations of symbols. 


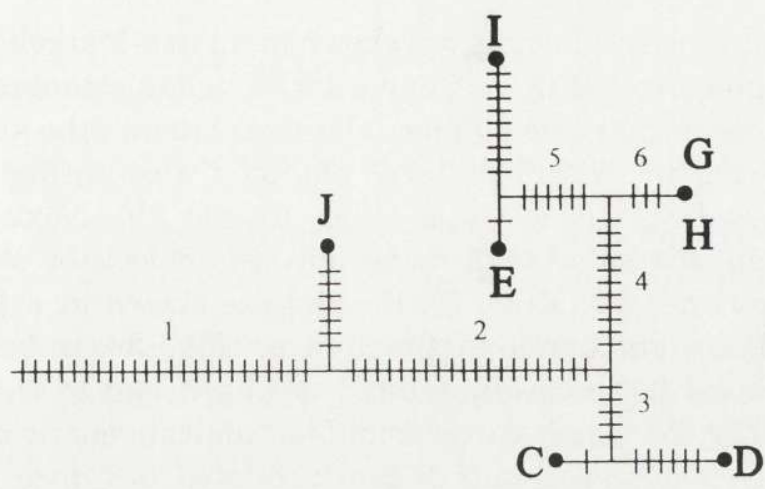

Fig. 3. HENNIGian cladogram (based on 96 behavioural character states) showing phylogenetic relationships among genera of the Caprinae (C - Oreamnos, D - Rupicapra, E - Ammotragus, G Hemitragus, H - Capra, I - Ovis). The nilgai antelope Boselaphus tragocamelus (J) serves as outgroup. Sector 1: symplesiomorphic character states (functional category in parentheses, ${ }^{*}$ - character state present in all members of the subsequent clade): $\mathrm{Ch}(\mathrm{AA})^{*}, \mathrm{Ki}(-)(\mathrm{AA}), \mathrm{Hp}(-)(\mathrm{AA}), \mathrm{Ga}(-)(\mathrm{TD})$, $\mathrm{Hd}(-)(\mathrm{TD}), \mathrm{St}(-)(\mathrm{DD}), \mathrm{Pw}(-)(\mathrm{DD})^{*}, \mathrm{Ls}(-)(\mathrm{DD}), \mathrm{Mt}(-)(\mathrm{DD}), \mathrm{Ts}(-)(\mathrm{DD}), \mathrm{Fl}(-)(\mathrm{DD})^{*}, \mathrm{He}(-)(\mathrm{DD})^{*}$, $\mathrm{Uf}(-)(\mathrm{SD}), \mathrm{Rb}(-)(\mathrm{SD}), \mathrm{Nn}(\mathrm{CD})^{*}, \mathrm{Ng}(\mathrm{CD})^{*}, \mathrm{Fl}(\mathrm{CD})^{*}, \mathrm{~T}(-)(\mathrm{CD}), \mathrm{Ls}(\mathrm{CD}), \mathrm{Ct}(\mathrm{CD}), \mathrm{Hu}(\mathrm{CD})^{*}, \mathrm{Ki}(-)(\mathrm{CD})$, $\mathrm{Ap}(\mathrm{CD}), \mathrm{Pa}(-)(\mathrm{MA})$. Sector 2: character states synapomorphic for the clade Caprinae. Rf(AA), Rf(-)(AA), Bt(AA)*, Hr(TD), Hk(TD)*, Lu(TD)*, Hd(TD), Hs(TD), St(DD), Ht(DD), Hu(-)(DD), Pw(DD), $\mathrm{Su}(\mathrm{DD}), \mathrm{Mp}(\mathrm{DD}), \mathrm{Ki}(\mathrm{CD}), \mathrm{Ap}(-)(\mathrm{CD}), \mathrm{Dp}(-)(\mathrm{MA})^{*}, \mathrm{Ho}(\mathrm{MA})^{*}, \mathrm{Bf}(\mathrm{MA}), \mathrm{Pa}(\mathrm{MA})$. Sector 3: character states synapomorphic for the clade Rupicaprini. Ga(TD), Ls(SD), Th(CD), Fs(CD), Ms(MA). Sector 4 character states synapomorphic for the clade Caprini. Nf(AA), Co (AA)*, $\mathrm{Hu}(\mathrm{DD}), \mathrm{Bl}(\mathrm{DD}), \mathrm{Tf}(\mathrm{DD})$, $\mathrm{Nl}(\mathrm{SD}), \operatorname{Tv}(\mathrm{CD}), \operatorname{Tr}(\mathrm{CD})^{*}, \operatorname{Ts}(\mathrm{CD})^{*}, \operatorname{Tf}(\mathrm{CD}), \mathrm{Ks}(\mathrm{CD})$. Sector 5: character states synapomorphic for the clade E/I. Sp(AA), Hp(AA), Cr(AA), Ls(DD), Mt(DD), Ls(-)(SD). Sector 6: character states synapomorphic for the clade G/H. $\mathrm{Cu}(\mathrm{AA}), \mathrm{Ju}(\mathrm{TD}), \mathrm{Kf}(\mathrm{CD})$. Character states autapomorphic for J: Nk(AA), Ck(AA), Dd(TD), Hf(DD), Su(-)(DD), Dp(MA), Ho(-)(MA); for C: $\operatorname{Dr}(\mathrm{MA})$; for D: Fl(DD), $\mathrm{Bs}(\mathrm{DD}), \mathrm{Pd}(\mathrm{DD}), \mathrm{Uf}(\mathrm{SD}), \mathrm{Mk}(\mathrm{CD}), \mathrm{Pa}(\mathrm{CD})$; for $\mathrm{E}$ : $\mathrm{Dw}(\mathrm{MA})$, and for I: $\mathrm{Ki}(\mathrm{AA}), \mathrm{Cp}(\mathrm{AA}), \mathrm{Jf}(\mathrm{TD}), \mathrm{Ts}(\mathrm{DD})$, $\operatorname{Tr}(\mathrm{DD}), \mathrm{He}(\mathrm{DD}), \mathrm{Ej}(\mathrm{DD}), \mathrm{Rb}(\mathrm{SD}), \mathrm{Hb}(\mathrm{SD})$. There are no autapomorphic character states for $\mathrm{G}$ and $\mathrm{H}$ See Appendix and Table 1 for explanations of symbols.

(a)

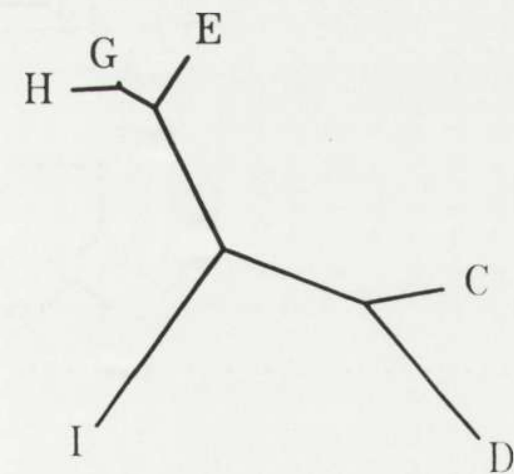

(b)

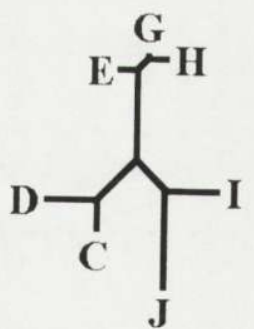

Fig. 4. Fitch-Margoliash tree (a) and maximum-parsimony tree (b) showing phylogenetic relationships among genera of the Caprinae. The trees are based on 23 character states (courtship displays). In (a) the distance from $\mathrm{E}$ to the node corresponds to a total distance of 0.052 . In (b) the distance from $\mathrm{E}$ to the node represents 1 character state transformation. J - Boselaphus tragocamelus (outgroup), C Oreamnos, D - Rupicapra, E-Ammotragus, G - Hemitragus, H - Capra, I - Ovis. 
biochemical-genetic analyses. Results are shown in a Fitch-Margoliash tree (Fig. 1a), a maximum parsimony tree (Fig. 2a), and a HENNIGian cladogram (Fig. 3). With the exception of Ammotragus, being more closely related to the sheep on the basis of behavioural traits, the overall patterns obtained were rather similar to those based on biochemical-genetic analyses (Figs $1 \mathrm{~b}$ and $2 \mathrm{~b}$ ). Next we re-examined relationships among the same taxa using only the character states included in courtship behaviour ( $n=23$, Table 3). Results are shown in a Fitch-Margoliash tree (Fig. 4a), and in a maximum-parsimony tree (Fig. 4b). In both cases, Ammotragus was now found to be closely related to Capra and to Hemitragus, which more closely matches the expectations from biochemical-genetic results. Based on 96 character states, Ovis was more distantly related to Capra and Hemitragus than either Rupicapra or Oreamnos (Figs 1a and 2a). However, in Fig. 3 (96 character states) as well as in Figs $4 \mathrm{a}$ and $4 \mathrm{~b}$, both based on 23 character states, Ovis was more closely related to Capra and Hemitragus that either Rupicapra or Oreamnos. In a third approach all taxa available were included in analyses based on 23 character states (Fig. 5a, b). In both trees the genus Pseudois was situated close to a group comprising Capra, Hemitragus, and Ammotragus, while Capricornis and Nemorhaedus showed stronger affinities to Oreamnos, Rupicapra, and Ovis.

(a)

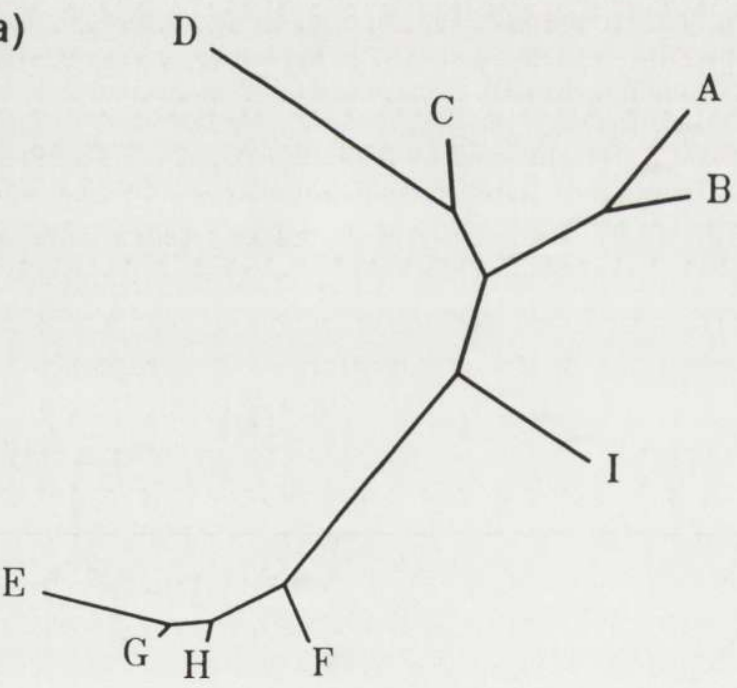

(b)

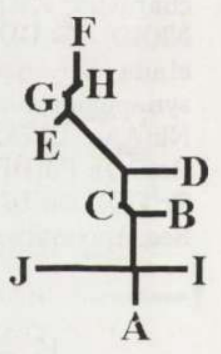

Fig. 5. Fitch-Margoliash tree (a) and maximum-parsimony tree (b) showing phylogenetic relationships among genera of the Caprinae. The trees are based on 23 character states (courtship displays). In (a) the distance from $B$ to the node corresponds to a total distance of 0.052 . In (b) the distance from B to the node represents 2 character state transformations. J - Boselaphus tragocamelus (outgroup), A Capricornis, B - Nemorhaedus, C - Oreamnos, D - Rupicapra, E - Ammotragus, F - Pseudois, G Hemitragus, H - Capra, I - Ovis. 


\section{Discussion}

The results of our analyses show that phylogenetic trees based on behavioural elements are generally in good agreement with those obtained from allozyme analyses. This suggests that classical ethology in the way proposed by Heinroth (1910) can serve as a powerful tool in taxonomy. Depending on the respective tree-building algorithm chosen, either Rupicapra or Ovis was slightly more closely related to Capra. Thus, using the set of behaviours considered in the present study, we were not able to resolve the Capra-Ovis-Rupicapra trichotomy pointed out in biochemical-genetic studies (Hartl et al. 1990a, b, Randi et al. 1991). As found in allozymes (Hartl and Willing 1987), also the choice of characters (all characters vs characters involved in courtship and mating) strongly influenced relationships among these three taxa. Regarding behaviours, this also holds for the systematic position of Ammotragus. Using all characters the aoudad was almost exactly intermediate between sheep and goats, as postulated by Geist (1971). This is in sharp contrast to biochemical-genetic data, according to which the aoudad is clearly related to the goat (Hartl et al. 1990b). However, regarding the analysis of all characters used in our study it must be emphasized that certain displays may look very similar to the investigator, but are actually not homologous (eg Walther 1966). Such characters are found in all fuctional categories, but are especially rare in courtship behaviour and mating. Several of the behaviours involved in the latter category can be considered more ore less ritualized derivates from agressive acts and from behaviour between infant and mother (eg Walther 1966, Rice 1995).

For example, rear twist (Tr), side twist (Ts), mock suck (Mk), and tongue flick (Tf) can be considered derivates from suckling behaviour (Aeschbacher 1978, Lovari 1985, Rice 1995). Courtship displays can function as releasers of female mating activity, as suggested by Aeschbacher (1978) for the Alpine ibex (Capra ibex). In this case courtship displays would act as effective barriers to hybridization of closely related species (Lovari 1985). A different opinion was expressed by Schaller (1977), who stated that external morphological features, such as horns, are more important than male courtship behaviour for triggering female mating activity. As can be seen from Fig. 3, autapomorphies in sheep, a group characterized by tremendous differences in horn size and shape, entirely belong to functional categories other than courtship. Contrary to this, genera less differentiated in horns, such as the chamois or the Rocky Mountain goat, show autapomorphic courtship displays. Indeed, if only characters involved in courtship are considered, the position of the aoudad in phylogenetic trees is very similar to that inferred from biochemical-genetic data (Figs 1b, 2b, and 4a, b). From these considerations we conclude that behaviours involved in courtship and mating are the most reliable ones for systematic investigations. Based only on the characters involved in courtship and mating, the genera Capricornis and Nemorhaedus are clearly related to Rupicapra and Oreamnos, which conforms with the current 
classification (Thenius 1969). However, there are also affinities to Ovis, which are stronger than in either Rupicapra or Oreamnos. Pseudois is closely related to Capra, Hemitragus, and Ammotragus (Fig. 5a, b), and indeed this taxon has been assumed to represent a basic goat by Schaller (1977). According to these results the inclusion of the serow, the goral, and the bharal in further genetic investigations is paramount for resolving the Capra-Ovis-Rupicapra trichotomy.

Acknowledgements: This study was supported by the Austrian Research Foundation (FWF, project P09660-BIO, granted to G. B. Hartl).

\section{References}

Aeschbacher A. 1978. Das Brunftverhalten des Alpensteinwildes (Capra ibex ibex L.). Eugen Rentsch Verlag, Erlenbach-Zürich: 1-74.

Akasaka T. and Maruyama N. 1977. Social organization and habitat use of Japanese serow in Kasabori. Journal of the Mammalogical Society of Japan 7: 87-102.

Dane B. 1977. Mountain goat social behaviour: Social structure and "play" behaviours as affected by dominance. Proceedings of the 1st International Mountain Goat Symposium. Kalispell (Montana, USA). Province of British Columbia, Ministry of Recreation and Conservation, Fish and Wildlife Branch: 92-106.

DeBock E. 1970. On the behavior of the Mountain Goat (Oreamnos americanus) in Kootenai National Park. Unpublished M Sc thesis, Department of Zoology, University of Edmonton, Alberta.

Cavallini P. 1987. On the behaviour of male Sardinian mouflons (Ovis orientalis musimon) during the pre-rut. Mammalia 51: 195-200.

Estes R. D. 1991. The behavior guide to African mammals. The University of California Press, Berkeley: 1-611.

Felsenstein J. 1993. PHYLIP (Phylogeny Inference Package), version 3.5c. Department of Genetics, University of Washington, Seattle.

Geist V. 1964. On the rutting behaviour of the mountain goat. Journal of Mammalogy 45: 551-568.

Geist V. 1971. Mountain sheep - A study in behavior and evolution. University of Chicago Press, Chicago and London: 1-381.

Haas G. 1959. Untersuchungen über angeborene Verhaltensweisen beim Mähnenspringer (Ammotragus lervia). Zeitschrift für Tierpsychologie 16: 218-242.

Habibi K. 1987. Behaviour of aoudad (Ammotragus lervia) during the rutting season. Mammalia 51: 497-513.

Hartl G. B. 1995. Molecular genetics of the Caprinae: Implications for phylogeny, conservation, and management. [In: CIC Caprinae atlas. N. Franco, ed]. (in press).

Hartl G. B., Burger H., Willing R. and Suchentrunk F. 1990b. On the biochemical systematics of the Caprini and the Rupicaprini. Biochemical Systematics and Ecology 18: 175-182.

Hartl G. B. and Willing R. 1987. On the biochemical genetics of the Alpine ibex (Capra ibex ibex L.). [In: Lo stambecco delle Alpi: Realta attuale e prospettive. T. Balbo, D. DeMeneghi, P. G. Meneguz and L. Rossi, eds]. Università di Torino, Torino: 3-9.

Hartl G. B., Willing R. and Suchentrunk F. 1990a. On the biochemical systematics of selected mammalian taxa: empirical comparison of qualitative and quantitative approaches in the evaluation of protein electrophoretic data. Zeitschrift für zoologische Systematik und Evolutionsforschung 28: 191-216.

Heinroth O. 1910. Beiträge zur Biologie, namentlich Ethologie und Psychologie der Anatiden. Verhandlungsberichte des Internationales Ornithologiekongresses Berlin: 600-615.

Kishimoto R. 1989. Social organization of a solitary ungulate, the Japanese serow Capricornis crispus. Unpublished Ph D thesis, Osaka City University, Osaka. 
Krämer A. 1969. Soziale Organisation und Sozialverhalten einer Gemspopulation (Rupicapra rupicapra L.) der Alpen. Zeitschrift für Tierpsychologie 26: 889-964.

Lovari S. 1985. Behavioural repertoire of the Abruzzo chamois (Rupicapra pyrenaica ornata). Säugetierkundliche Mitteilungen 32: 113-136.

Lovari S. and Apollonio M. 1994. On the rutting behaviour of the Himalayan Goral Nemorhaedus goral (Hardwicke, 1825). Journal of Ethology 12: 24-34.

Nei M. 1978. Estimation of average heterozygosity and genetic distance from a small number of individuals. Genetics 89: 583-590.

Petzsch H. and Witstruk K. 1958. Beobachtungen an daghestanischen Turen (Capra caucasica cylindricornis Blyth) im Berg-Zoo Halle. Der Zoologische Garten 25: 6-19.

Quicke D. L. J. 1993. Principles and techniques of contemporary taxonomy. Blackie Academic \& Professional, London: 1-311.

Randi E., Fusco G., Lorenzini R., Toso S. and Tosi G. 1991. Allozyme divergence and phylogenetic relationships among Capra, Ovis, and Rupicapra (Artiodactyla, Bovidae). Heredity 67: 281-286.

Rice C. C. 1988. Agonistic and sexual behaviour of Nilgiri tahr (Hemitragus hylocrius). Ethology 87: 89-112.

Rice C. C. 1995. On the origin of sexual displays in caprids. Zeitschrift für Säugetierkunde 60: 53-62.

Sakurai M. 1981. Socio-ecological study of the Japanese serow, Capricornis crispus (Temnick) (Mammalia: Bovidae) with special reference to the flexibility of its social structure. Japanese Journal of Ecology and Physiology 18: 163-212

Schaller G. B. 1977. Mountain monarchs - Wild sheep and goats of the Himalaya. University of Chicago Press, Chicago and London: $1-425$.

Schaller G. B. and Laurie A. 1974. Courtship behaviour of the wild goat. Zeitschrift für Säugetierkunde 39: 115-127.

Schaller G. B. and Mirza Z. 1974. On the behaviour of Punjab urial (Ovis orientalis punjabiensis). [In: The behaviour of ungulates and its relation to management. V. Geist and F. Walther, eds]. IUCN Publications, New Series 24(1): 306-323.

Soma H. and Zhiwotschenko V. 1988. Seraue (Gattung Capricornis) und Gorale (Gattung Nemorhaedus). [In: Grzimek's Enzyklopädie. B. Grzimek, ed]. Kindler Verlag, München 5: 505-507.

Thenius E. 1969. Phylogenie der Mammalia. Stammesgeschichte der Säugetiere (einschließlich der Hominoidea). Walter de Gruyter, Berlin: 1-722.

Walther F. 1966. Mit Horn und Huf. Paul Parey, Berlin and Hamburg: 1-171.

Walther F. 1974. Some reflections on expressive behaviour in combats and courtship of certain horned ungulates. [In: The behavour of ungulates and its relation to management. V. Geist and F. Walther, eds]. IUCN Publications, New Series 24(1): 56-106.

Wilson P. 1984. Aspects of reproductive behaviour of bharal (Pseudois nayaur) in Nepal. Zeitschrift für Säugetierkunde 49: 36-42.

Received 7 August 1995, accepted 1 September 1995. 
APPENDIX. Socio-ethogram according to Haas (1959), Petzsch and Witstruk (1958), Geist (1964, 1971), Walther (1966, 1974), Krämer (1969), DeBock (1970), Schaller and Laurie (1974), Schaller and Mirza (1974), Akasaka and Maruyama (1977), Dane (1977), Schaller (1977), Sakurai (1981), Wilson (1984), Lovari (1985), Cavallini (1987), Habibi (1987), Rice (1988, 1995), Soma and Zhiwotschenko (1988), Kishimoto (1989), Lovari and Apollonio (1994). The following functional categories are distinguished: aggressive actions (AA), threat displays (TD), dominance displays (DD), submissive displays (SD), courtship displays and mating (CD), and marking (MA). Character states marked by an asterisk are shown only by the outgroup (Boselaphus tragocamelus).

\begin{tabular}{|c|c|c|}
\hline $\begin{array}{l}\text { Character state } \\
\text { (abbreviation, synonyms) }\end{array}$ & $\begin{array}{l}\text { Functional } \\
\text { category }\end{array}$ & Description \\
\hline 1 & 2 & 3 \\
\hline $\begin{array}{l}\text { Anterior chest-pressing } \\
\text { (Ap) }\end{array}$ & $\mathrm{CD}$ & A male presses his chest against the rear of a female. \\
\hline $\begin{array}{l}\text { Block } \\
(\mathrm{Bl})\end{array}$ & DD & $\begin{array}{l}\text { To halt the advance of one male another and larger } \\
\text { male typically moves in front of him and stays broad- } \\
\text { side. Block is a special form of Ht. }\end{array}$ \\
\hline $\begin{array}{l}\text { Body-head shake } \\
\text { (Bs) }\end{array}$ & DD & $\begin{array}{l}\text { The initiator starts by shaking the body, but the move- } \\
\text { ment accelerates during performance. At the same time } \\
\text { urine may be eliminated, thus impregnating the flank } \\
\text { pelage. A head-shake may follow. }\end{array}$ \\
\hline $\begin{array}{l}\text { Bump forehead } \\
(\mathrm{Bf})\end{array}$ & MA & $\begin{array}{l}\text { Pressing of forehead against vegetation, often while or } \\
\text { immediately after Su. }\end{array}$ \\
\hline Butt & AA & $\begin{array}{l}\text { Swinging the head down and bringing the front of the } \\
\text { horns into contact with the partner. }\end{array}$ \\
\hline $\begin{array}{l}\text { Chase } \\
\text { (Ch) }\end{array}$ & AA & $\begin{array}{l}\text { An individual pursues another for several tens of } \\
\text { meters. }\end{array}$ \\
\hline $\begin{array}{l}\text { Clash, head-on } \\
\text { (Co, head-on butt) }\end{array}$ & AA & $\begin{array}{l}\text { Both partners lower their heads to make contact with } \\
\text { their horns in form of a quick sharp blow or by pressing } \\
\text { their horns together. }\end{array}$ \\
\hline $\begin{array}{l}\text { Clash, rear upright } \\
\quad(\mathrm{Cu})\end{array}$ & AA & $\begin{array}{l}\text { The initiator rears bolt upright, standing balanced on } \\
\text { his hindlegs, and lunges down to hit the horns of a } \\
\text { waiting opponent. Occasionally both opponents rear } \\
\text { and clash in unison. }\end{array}$ \\
\hline $\begin{array}{l}\text { Clash, running } \\
\text { (Cr) }\end{array}$ & AA & $\begin{array}{l}\text { One or both combattants run at the other from a } \\
\text { distance and ram head on. }\end{array}$ \\
\hline $\begin{array}{l}\text { Clash, running on hindlegs } \\
\text { (Cp) }\end{array}$ & $\mathrm{AA}$ & $\begin{array}{l}\text { One or both combattants partially rear up and, running } \\
\text { unbalanced on their hindlegs, fling themselves into a } \\
\text { clash. }\end{array}$ \\
\hline $\begin{array}{l}\text { Clash, kneeling* } \\
\text { (Ck) }\end{array}$ & AA & $\begin{array}{l}\text { One or both combattants "kneel" on the carpal joints } \\
\text { when clashing. }\end{array}$ \\
\hline Croup touch & $\mathrm{CD}$ & $\begin{array}{l}\text { Male rests and/or rubs his chin on the top of the rump } \\
\text { of the female. }\end{array}$ \\
\hline $\begin{array}{l}\text { Dig rutting pit } \\
\text { (Dr) }\end{array}$ & MA & $\begin{array}{l}\text { Sit on the ground and assume a posture not unlike a } \\
\text { sitting dog, and paw and dig vigourously with one front } \\
\text { leg, thereby throwing snow, sand, dirt at the belly, } \\
\text { hindlegs, and flanks. }\end{array}$ \\
\hline $\begin{array}{l}\text { Dig sand wallow } \\
\text { (Dw) }\end{array}$ & MA & $\begin{array}{l}\text { Paw and dig with one frontleg in sandy ground, } \\
\text { throwing sand on the belly, hindlegs, and flanks, and } \\
\text { wallowing in the sand. }\end{array}$ \\
\hline
\end{tabular}


APPENDIX continued.

\begin{tabular}{|c|c|c|}
\hline 1 & 2 & 3 \\
\hline $\begin{array}{l}\text { Dropping down* } \\
\text { (Dd) }\end{array}$ & $\mathrm{TD}$ & Dropping down onto "knees" and jerk. \\
\hline $\begin{array}{l}\text { Dung pile } \\
\text { (Dp) }\end{array}$ & MA & Deposition of dung (and urine) on a particular spot. \\
\hline $\begin{array}{c}\text { Ejaculation } \\
(\mathrm{Ej})\end{array}$ & DD & $\begin{array}{l}\text { A male suddenly crouches in the rear, protrudes the } \\
\text { penis sideways past the frontlegs, and staggers stiff- } \\
\text {-legged forward or steps around in a narrow circle } \\
\text { while ejaculating. }\end{array}$ \\
\hline $\begin{array}{l}\text { Flank stroke } \\
\text { (Fs) }\end{array}$ & $\mathrm{CD}$ & $\begin{array}{l}\text { Male softly caresses the hindquarter of the female with } \\
\text { the inner surface of a foreleg. }\end{array}$ \\
\hline $\begin{array}{l}\text { Flehmen } \\
\text { (Fl, lip curl) }\end{array}$ & $\mathrm{DD}, \mathrm{CD}$ & $\begin{array}{l}\text { Male curls his upper lip after sniffing scent or urine of } \\
\text { the female. }\end{array}$ \\
\hline $\begin{array}{r}\text { Gambol } \\
(\mathrm{Ga})\end{array}$ & TD & $\begin{array}{l}\text { A downhill run that includes vigorous head nodding } \\
\text { and alternately throwing up the fore- and the hind- } \\
\text { quarters. }\end{array}$ \\
\hline $\begin{array}{l}\text { Head down } \\
\text { (Hd, hunch) }\end{array}$ & TD & $\begin{array}{l}\text { Head held lower than the main axis of the body; muzzle } \\
\text { pointing towards the ground or tucked close to the } \\
\text { neck, and back more or less humped. Ears turned } \\
\text { backwards. }\end{array}$ \\
\hline $\begin{array}{l}\text { Head forward* } \\
\text { (Hf) }\end{array}$ & DD & $\begin{array}{l}\text { Broadside and frontal dominance display, head and } \\
\text { neck in a stretched forward position. }\end{array}$ \\
\hline $\begin{array}{l}\text { Head out } \\
\text { (Ht, broadside) }\end{array}$ & DD & $\begin{array}{l}\text { Initiator stands broadside to an opponent with body } \\
\text { erect and with chin tucked in. After a few seconds one } \\
\text { or both animals may circle each other. }\end{array}$ \\
\hline $\begin{array}{l}\text { Head-up } \\
(\mathrm{Hu})\end{array}$ & $\mathrm{DD}, \mathrm{CD}$ & $\begin{array}{l}\text { The initiator approaches the partner with stiff and } \\
\text { abrupt steps, uplifting his muzzle. Ears hold sideways. }\end{array}$ \\
\hline $\begin{array}{l}\text { Hook } \\
\text { (Hk, jerk) }\end{array}$ & $\mathrm{TD}$ & $\begin{array}{l}\text { The initiator may attempt to gore or feign towards the } \\
\text { partner using an upward sweep of his horns. }\end{array}$ \\
\hline $\begin{array}{r}\text { Horning } \\
(\mathrm{Ho})\end{array}$ & MA & $\begin{array}{l}\text { Frontal "attack" on a bush or a low branch and sniffing } \\
\text { at the horned vegetation. }\end{array}$ \\
\hline $\begin{array}{l}\text { Horning body } \\
\text { (Hb) }\end{array}$ & SD & $\begin{array}{l}\text { A subordinate male horns face, neck, chest or shoulder } \\
\text { of a dominant male. }\end{array}$ \\
\hline $\begin{array}{l}\text { Horn present } \\
(\mathrm{Hr})\end{array}$ & TD & $\begin{array}{l}\text { The initiator orients towards the recipient, lowers the } \\
\text { head and pulls in the chin, directing the front of the } \\
\text { horns towards the opponent. }\end{array}$ \\
\hline $\begin{array}{l}\text { Horn pull } \\
(\mathrm{Hp})\end{array}$ & AA & $\begin{array}{l}\text { Opponents stand parallel and one hooks his horn } \\
\text { through the horn of the other after which the two pull } \\
\text { sideways. }\end{array}$ \\
\hline $\begin{array}{l}\text { Huddle } \\
(\mathrm{He})\end{array}$ & DD & $\begin{array}{l}\text { Rapid exchange of aggressive actions between several } \\
\text { males in a group. }\end{array}$ \\
\hline $\begin{array}{l}\text { Hunch siddle } \\
(\mathrm{Hs})\end{array}$ & TD & $\begin{array}{l}\text { The initiator hunches the back, twists the head so that } \\
\text { the muzzle points towards the opponent (and the horns } \\
\text { away), and steps sideways towards the opponent. }\end{array}$ \\
\hline Jump threat, forward & $\mathrm{TD}$ & $\begin{array}{l}\text { The initiator stands leaning forward on his hindlegs } \\
\text { while facing or standing sideways to the opponent, with } \\
\text { chin tucked in and turned to one side, and with forelegs } \\
\text { hanging loosely. }\end{array}$ \\
\hline
\end{tabular}


APPENDIX continued.

\begin{tabular}{|c|c|c|}
\hline 1 & 2 & 3 \\
\hline $\begin{array}{l}\text { Jump threat, upright } \\
(\mathrm{Ju})\end{array}$ & TD & $\begin{array}{l}\text { Initiator stands upright on the hind legs while facing } \\
\text { or standing sideways to the opponent, with chin tucked } \\
\text { in and turned to one side, and with forelegs bent and } \\
\text { held close to the body. }\end{array}$ \\
\hline $\begin{array}{l}\text { Kick stiff } \\
\quad \text { (Ki, front kick) }\end{array}$ & $\mathrm{AA}, \mathrm{CD}$ & $\begin{array}{l}\text { An individual kicks another's body with a stretched } \\
\text { foreleg. }\end{array}$ \\
\hline $\begin{array}{l}\text { Kick stiff, intentional } \\
(\mathrm{Ks})\end{array}$ & $\mathrm{CD}$ & $\begin{array}{l}\text { The initiator kicks towards the body of a partner with } \\
\text { a stretched foreleg. }\end{array}$ \\
\hline $\begin{array}{l}\text { Kick flexed } \\
\text { (Kf) }\end{array}$ & $\mathrm{CD}$ & $\begin{array}{l}\text { The initiator kicks towards another's body with flexed } \\
\text { carpal joints. }\end{array}$ \\
\hline
\end{tabular}

Low-stretch

(Ls)

Lunge

(Lu)

Marking female

(Mf)

Marking with preorbital gland (Mv)

Marking with supraoccipital gland $(\mathrm{Ms})$

Mock suck

(Mk)

Mounting

(Mt)

Mouth penis

(Mp)

Naso-anogenital contact

$(\mathrm{Ng})$

Naso-nasal contact (Nn, nose contact)

Neck fight

Neck fight kneeling* $(\mathrm{Nk})$

Neck low (NI)

Parallel walk

$(\mathrm{Pw})$

DD, SD, CD The initiator approaches a partner, flexes the carpal joints, and lowers but outstretches his neck, with the chin slightly raised and the horns held parallel to the neck.

MA

DD

AA

DD

Horn present combined with a rapid rush at the opponent.

A male rubs his preorbital glands against horns, ears, and anogenital region of a female.

A The frontal and parietal regions of the head are gently rubbed on vegetation. Preorbital glands may be used.

The supraoccipital glands are slid up and down on a grass stem or a thin twig, presumably to deposit scent. forelegs, inserts his muzzle under the utter region of the female and delivers two to three blows.

The initiator mounts a partner.

Tuck in the rump and twist the muzzle towards the bare penis, nuzzling the penis and/or insert it into the mouth. The mouth, face and beard may be doused with urine. Ejaculation may occur. region of a partner with his nose.

The initiator touches or nearly touches another's nose with his own.

The opponents adopt a variety of orientations, from frontal to nearly parallel, and push against each others necks and/or try to place the ventral part of their necks over the neck or shoulder of the other and push downward.

A As Nf. But opponents "kneel" on the carpal joints. on the forelegs.

Two males walk or trot parallel 0.5 to $4 \mathrm{~m}$ apart, their horns tipped towards each other. Sometimes their posture is normal or only slightly erect and at other times they display a $\mathrm{Hu}$ or a $\mathrm{Hd}$. 
APPENDIX concluded.

\begin{tabular}{|c|c|c|}
\hline 1 & 2 & 3 \\
\hline $\begin{array}{l}\text { Paw } \\
\qquad(\mathrm{Pa}, \text { stamp })\end{array}$ & $\mathrm{CD}, \mathrm{MA}$ & Paw or stamp with a foreleg. \\
\hline $\begin{array}{l}\text { Penil display } \\
(\mathrm{Pd})\end{array}$ & DD & $\begin{array}{l}\text { The male crouches in the rear, squats slightly and } \\
\text { unsheads his penis between the frontlegs. Ejaculation } \\
\text { may occur. }\end{array}$ \\
\hline $\begin{array}{l}\text { Reverse parallel fighting } \\
\text { (Rf, head to tail) }\end{array}$ & AA & $\begin{array}{l}\text { The opponents stay parallel to each other, but facing } \\
\text { in the opposite direction. The contact includes pushing } \\
\text { against the partner with the shoulder, turning the } \\
\text { horns towards the opponent's flank and/or hook his fore } \\
\text { and hind legs. }\end{array}$ \\
\hline $\begin{array}{l}\text { Rubbing } \\
\text { (Rb) }\end{array}$ & SD & $\begin{array}{l}\text { A subordinate male rubs his face on the face of a } \\
\text { dominant male. }\end{array}$ \\
\hline $\begin{array}{l}\text { Shoulder push } \\
\quad \text { (Sp, parallel shoulder push) }\end{array}$ & AA & $\begin{array}{l}\text { The opponents stay parallel to each other, and push } \\
\text { and lean against each other. }\end{array}$ \\
\hline $\begin{array}{l}\text { Spraying urine } \\
(\mathrm{Su})\end{array}$ & DD & $\begin{array}{l}\text { Squirt or spray urine with erected, and up and down } \\
\text { flicking penis, directing the flow of urine on belly, } \\
\text { chest, throat, and chin. }\end{array}$ \\
\hline $\begin{array}{l}\text { Stare } \\
\text { (St) }\end{array}$ & DD & $\begin{array}{l}\text { The (dominant) initiator looks intently at a (sub- } \\
\text { ordinate) partner until the latter moves away or shows } \\
\text { submissive behaviour. }\end{array}$ \\
\hline $\begin{array}{l}\text { Tail up horizontal } \\
\text { (Th) }\end{array}$ & $\mathrm{CD}$ & Tail is raised horizontally. \\
\hline $\begin{array}{l}\text { Tail up vertical } \\
\text { (Tv) }\end{array}$ & $\mathrm{CD}$ & Tail is raised vertically or folded over against the rump. \\
\hline $\begin{array}{l}\text { Tongue flick } \\
\text { (Tf) }\end{array}$ & $\mathrm{DD}, \mathrm{CD}$ & The tongue is more or less rapidly flicked in and out. \\
\hline $\begin{array}{l}\text { Twist rear } \\
\quad(\mathrm{Tr})\end{array}$ & $\mathrm{DD}, \mathrm{CD}$ & $\begin{array}{l}\text { A male stands behind a partner and, twisting his head } \\
\text { sideways, extends his neck and muzzle forward, in the } \\
\text { direction of or to the hind part of the partner's belly. }\end{array}$ \\
\hline $\begin{array}{l}\text { Twist side } \\
\text { (Ts) }\end{array}$ & DD, CD & $\begin{array}{l}\text { A male stands besides a partner and lowers his head, } \\
\text { twisting it axially, and moves his head towards the } \\
\text { partner so that his muzzle points at or touches its belly. }\end{array}$ \\
\hline $\begin{array}{l}\text { Urinating in female posture } \\
\text { (Uf) }\end{array}$ & SD & Urinating with flexed hind legs. \\
\hline
\end{tabular}

